\title{
Production of lightweight Geopolymer concrete using artificial local lightweight aggregate
}

\author{
Waleed Abbas ${ }^{1}$, Wasan Khalil $^{1}$, and Ibtesam Nasser*² \\ ${ }^{1}$ Building and Construction Engineering Department, University of Technology, Baghdad, Iraq \\ ${ }^{2}$ Middle Technical University, Baghdad, Iraq
}

\begin{abstract}
Due to the rapid depletion of natural resources, the use of waste materials and by-products from different industries of building construction has been gaining increased attention. Geopolymer concrete based on Pozzolana is a new material that does not need the presence of Portland cement as a binder. The main focus of this research is to produce lightweight geopolymer concrete (LWGPC) using artificial coarse lightweight aggregate which produced from locally available bentonite clays. In this investigation, the binder is low calcium fly ash (FA) and the alkali activator is sodium hydroxide and sodium silicate in different molarities. The experimental tests including workability, fresh density, also, the compressive strength, splitting tensile strength, flexural strength, water absorption and ultrasonic pulse velocity at the age of 7, 28 and 56 days were studied. The oven dry density and thermal conductivity at 28 days age are investigated. The results show that it is possible to produce high strength lightweight geopolymer concrete successfully used as insulated structural lightweight concrete. The 28-day compressive strength, tensile strength, flexural strength, dry density, and thermal conductivity of the produced LWGPC are $35.8 \mathrm{MPa}$, 2.6MPa, $5.5 \mathrm{MPa}, 1835 \mathrm{~kg} / \mathrm{m} 3$, and $0.9567 \mathrm{~W} /(\mathrm{m} . \mathrm{K})$, respectively.
\end{abstract}

\section{Introduction}

Environmental pollution is the most severe problem that the world is facing today. In the construction industry, the production of ordinary Portland cement (OPC) causes emission of pollutants which result in environmental pollution[1], are being made in the construction industry to address this by developing alternative binders in concrete.

The use of geopolymer technology is one of these alternatives. Geopolymer binders produced from a chemical reaction between silica and alumina molecules that contained in an active pozzolanic material (such as fly ash) react in highly alkaline conditions [3]. The resulting gel binder reacts to produce geopolymer concrete (GPC). The gradual growth of a global effort to minimize greenhouse gas emissions has grown because it has been found that one ton of OPC production needs about 2.8 ton of raw materials, such as limestone and coal, besides releases about 0.7 ton of carbon dioxide $\left(\mathrm{CO}_{2}\right)$ into the earth's atmosphere due to the decarbonation of lime in the kiln [4]. Approximately $12 \%$ of the total $\mathrm{CO}_{2}$ emissions into the earth's atmosphere emitted from the consumption of fossil fuels for commercial and residential heating accounts. In addition, huge amounts of $\mathrm{CO}_{2}$ are emitted from facilities cooling. As a result, the improvement of energy saving systems and new renewable energy sources has become one of the major issues in building structures. The use of lightweight concrete as a building material is very effective in saving energy because of the increase in thermal insulation capacity through the flagging thermal conductivity of lightweight aggregates [5]. Furthermore, the application of structural lightweight concrete has some useful advantages such as, the reduction of the dead load, and a lower density of concrete allows for using smaller and lighter weight structural member that increases the available space and enhances the seismic resistance capacity of the upper structures. In addition, the smaller and lighter elements of precast concrete members are used to make the lifting and transporting system less expensive [6]. Promote effects are expected when fly ash binder and lightweight aggregates are combined to produce environmentally eco-friendly concrete because of the great advantages of both materials. First significant effect is the excellent reduction in $\mathrm{CO}_{2}$ emission from concrete building structures by the use of fly ash (FA) binder with an energy-saving effect due to the use of lightweight aggregates. Thus, precast concrete can be produced with supreme quality and economic efficiency from an early higher strength development capacity of FA paste and a lower density of aggregates.

Since the construction industry is considered to be one of the rapid growing industries, minimizing the heat loss in buildings by increasing its thermal insulation

* Corresponding author: ibtesammhabbaba@yahoo.com 
properties is necessary, as it would enable energy efficient buildings and improved environmental sustainability. Besides, the utilization of industrial waste would be an added advantage [7]. Today, geopolymer is greatly diffuse in industry sector and considered acceptable alternative and has been used in many field applications like precast beams, boat ramp, pavement, bricks, retaining wall, water tanks, precast bridge, decks,...etc., $[8,4]$. Sachin[8] reports that using LECA as an artificial aggregate gives only $8 \mathrm{~N} / \mathrm{mm}^{2}$ without ambient curing temperature. Most researchers agreed that the curing temperature for curing Fly ash geopolymer concrete must be more than $60^{\circ} \mathrm{C}$ to increase ability to dissolve $\mathrm{Si}$ and $\mathrm{Al}$ in fly ash.

The aim of this research is to produce lightweight geopolymer concrete (LWGPC) with high strength, using artificial coarse lightweight aggregate which is produced from byproducts.

\section{Research significance}

A lot of researches examined the mechanical properties of GPC and indicated this material as a green or eco friendly material. Very little work was carried out on some properties of lightweight aggregate GPC. In this investigation high strength lightweight aggregate GPC was produced for the first time in Iraq from fly ash and local artificial lightweight aggregate with high compressive strength and low dry density. The beneficial consequence of producing high strength lightweight geopolymer concrete is to reduce the dead load of buildings, and enhance their thermal insulation, which makes this method a future construction alternative.

\section{Experimental program}

\subsection{Materials}

\subsubsection{Fly ash}

The fly ash used is recovered as a result of coal combustion during production of electricity from ISKENment-Turkey power station. It is a fine and glassy powder. The results indicate that the fly ash adopted satisfies the requirements of ASTM C 618[9]. The chemical composition of the used fly ash is presented in Table (I). The fly ash has a specific gravity of 2.33 and surface area of $773 \mathrm{~m}^{2} / \mathrm{kg}$.
Table 1. Chemical analysis of Fly ash*

\begin{tabular}{|c|c|}
\hline Oxide & Content, percent \\
\hline $\mathrm{SiO}_{2}$ & 59.56 \\
\hline $\mathrm{Al}_{2} \mathrm{O}_{3}$ & 29.33 \\
\hline $\mathrm{Fe}_{2} \mathrm{O}_{3}$ & 3.36 \\
\hline $\mathrm{CaO}$ & 2.20 \\
\hline $\mathrm{MgO}$ & 0.66 \\
\hline $\mathrm{SO}_{3}$ & 0.67 \\
\hline $\mathrm{Na}_{2} \mathrm{O}$ & 0.21 \\
\hline $\mathrm{K}_{2} \mathrm{O}$ & 2.02 \\
\hline L.O.I & 1.99 \\
\hline
\end{tabular}

Table 2. Chemical requirement for (ASTM C 618, 2005).

\begin{tabular}{|c|c|c|}
\hline Oxide composition & $\begin{array}{c}\text { Pozzolan class } \\
\mathrm{F}\end{array}$ & Fly ash \\
\hline $\mathrm{SiO}_{2}+\mathrm{Al}_{2} \mathrm{O}_{3}+\mathrm{Fe}_{2} \mathrm{O}_{3}$, min. percent & 70 & 89.73 \\
\hline $\mathrm{SO}_{3}$, max. percent & 5 & 0.67 \\
\hline Loss on ignition, max. percent & 6 & 2.77 \\
\hline
\end{tabular}

\subsubsection{The alkali-activated solutions}

The alkali-activated solution was used as a combination of two materials: sodium silicate $\left(\mathrm{Na}_{2} \mathrm{SiO}_{3}\right)$ solution and sodium hydroxide $(\mathrm{NaOH})$ solution to form the binder between the aggregates and other unreacted materials in the geopolymer concrete. Sodium hydroxide in the form of flakes $(\mathrm{NaOH}$ with $98 \%$ purity), and sodium silicate solution $\left(\mathrm{Na}_{2} \mathrm{O}=13.0 \%, \mathrm{SiO}_{2}=32.0 \%\right.$ and density $=$ $1.5 \mathrm{~g} / \mathrm{ml}$ at $20^{\circ} \mathrm{C}$, silicate viscosity (CPS) $20^{\circ} \mathrm{C}$ was $600)$ were used in this study. For preparing the solution of $1 \mathrm{M}, 40 \mathrm{~g}$ of $\mathrm{NaOH}$ flakes (molecular weight of $\mathrm{NaOH}=40$ ) was dissolved in one liter of distilled water. In this study different molar concentrations were produced depending on the ratio of caustic soda flakes to water. The solution was prepared a day before it was mixed with sodium silicate in order to be cool, then it was mixed with liquid sodium silicate in a weight proportion of (1: 2.5) (sodium hydroxide: sodium silicate) just before the mixing process.

\subsubsection{Fine aggregate}

Al-Ekhaider natural sand was used as fine aggregate of maximum size $4.75 \mathrm{~mm}$. Its gradation zone was (2). The results display that each of physical properties, sand grading and sulfate content were within the requirements of the Iraqi Specification No.45/1984. Its absorption, specific gravity, density and sulfate content are $1.8 \%, 2.6,1670 \mathrm{~kg} / \mathrm{m}^{3}$, and $0.12 \%$, respectively.

\subsubsection{Admixtures}

A high-range water reducing admixture DARACEM 19CFMQ was used. This type of super-plasticizer is liquid based sulphonated naphthalene and complies with the ASTM C494-2005 Types F[10].

\subsubsection{Coarse aggregate}


The coarse lightweight aggregate (LWA), used in this research was locally manufactured artificial lightweight aggregate produced from bentonite clay and water glass (sodium silicate) [10]. The manufacturing method of LWA has four main steps, the raw materials preparation, mixing of raw materials in proper ratios, firing the mixture to an adequate temperature and eventually the cooling process. Bentonite clay was mixed with sodium silicate liquid (clay: sodium silicate, 1:1 by weight). The clayey paste was twirled to form balls, and then they were dried at laboratory temperature for 24 hours, after that they were dried in an oven for 24 hours at $100{ }^{\circ} \mathrm{C}$ to ensure the complete drying. The rounded clay balls were burnt in an electrically heated furnace up to $800{ }^{\circ} \mathrm{C}$ firing temperature for soaking period of 2 hours. The fired balls were broken manually to smaller size by means of a hammer, and then screened on standard sieve series to fit the grading of coarse lightweight aggregate that conforms to ASTM C 330 Specifications[11]. The manufacturing steps that were carried out to produce the artificial LWA are shown in Fig. (I).
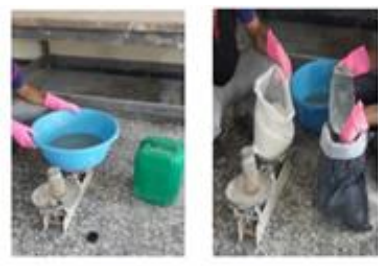

A) Weighting the silicate B) Weighting the Benton

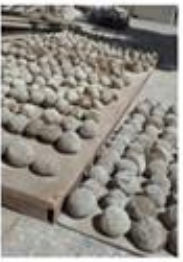

DuDoing the Paste

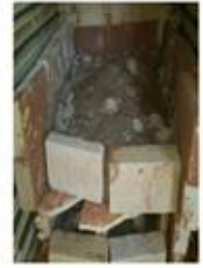

E) Firing the Paste

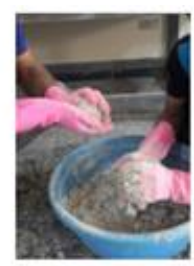

C) rolling the Paste to Ball

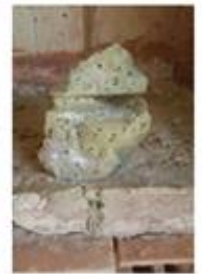

F) Cooling \& Crushing the Aggregate
Figure 1. Preparation of aggregates

\subsubsection{Water}

The water used in mixing the geopolymer concrete is potable water from the water supply network system. It was free from organic materials and suspended solids.

\subsection{Mixing, Casting, and Curing of Lightweight Geopolymer Concrete specimens}

Lightweight aggregates and natural sand were moistened for $24 \mathrm{~h}$ and then air-dried for another $24 \mathrm{~h}$ to imitate the saturated surface dried-state. The coarse and fine aggregates were mixed in the rotary drum mixer for about $3 \mathrm{~min}$, and then the fly ash was mixed with the aggregate for another 5 minutes. The alkaline liquid (Sodium silicate and the sodium hydroxide solutions) were maintained at room temperature for at least $24 \mathrm{~h}$ and then it was added to the mixture and mixed for not less than two minutes.

The super-plasticizer and the remaining water were finally mixed for two minutes and added to the mixture. Mixing was continued for another 4 minutes [11]. Then the initial slump was tested and the mixture was poured into varied steel molds to measure the mechanical properties.

Table 3. The properties of the produced coarse lightweight aggregate*

\begin{tabular}{|c|c|c|}
\hline Properties & $\begin{array}{c}\text { Test } \\
\text { Results of } \\
\text { Coarse } \\
\text { aggregate }\end{array}$ & Specification \\
\hline Absorption \% & 11.5 & ASTM C127 \\
\hline Specific gravity & 1.63 & ASTM C127 \\
\hline $\begin{array}{c}\text { Aggregate crushing } \\
\text { value } \%\end{array}$ & 773.31 & $\begin{array}{c}\text { BS 812-part } \\
110-1990\end{array}$ \\
\hline $\begin{array}{l}\text { Dry loose unit weight, } \\
\qquad\left(\mathrm{kg} / \mathrm{m}^{3}\right)\end{array}$ & $768.52 * *$ & $\begin{array}{c}\text { ASTM } \\
\text { 29/C29M }\end{array}$ \\
\hline $\begin{array}{l}\text { Dry rodded unit weight, } \\
\qquad\left(\mathrm{kg} / \mathrm{m}^{3}\right)\end{array}$ & 51.6 & $\begin{array}{c}\text { ASTM } \\
\text { 29/C29M }\end{array}$ \\
\hline$\underset{\%}{\text { Sulfate content }}\left(\mathrm{SO}_{3}\right)$ & $0.97 * * *$ & $\begin{array}{c}\text { BS 3797-part } \\
2-1981\end{array}$ \\
\hline Stain intensity***** & \multicolumn{2}{|c|}{ No stain } \\
\hline Stain index & 0 & ASTM 641 \\
\hline
\end{tabular}

${ }^{*}$ Physical analysis was conducted by National Center for Construction Laboratories and Researches .

***Within the limit of BS 3797 part $2 \leq 1.0 \%$

*** Within the limit of ASTM C330 $\leq 880 \mathrm{~kg} / \mathrm{m}^{3}$.

**** Staining material test was done in National Center for Construction Laboratories and Researches

The mixture was compacted to remove the entrapped air using vibrating table. Immediately after casting, the surface of the mixture was leveled and the specimens were covered using plastic film to reduce water loss. The specimens were kept in ambient condition for $24 \mathrm{~h}$. Then the specimens were cured in an oven for $48 \mathrm{~h}$ at $60^{\circ} \mathrm{C}$. Afterwards, the specimens were taken out of the oven and kept at ambient condition with an average temperature of $28^{\circ} \mathrm{C}$. The procedure of mixing has a major effect on workability and strength of geopolymer concrete.

Many researchers stated that geopolymer concrete can be manufactured by adopting the conventional techniques used in the manufacturing of Portland cement concrete [12][13].

\subsection{Experimental Tests}

Several tests were adopted in this investigation including:

- $\quad$ Slump test according to ASTM C143[14]. 
- $\quad$ Fresh density test according to ASTM C127[15].

- The compressive strength test according to (BS. 1881: Part 116:)( Cube specimens of $100 \mathrm{~mm}$ ) [16].

- The splitting tensile strength test according to (ASTM 496)(Cylinder specimens of $100 \times 200 \mathrm{~mm}$ ) [17].

- $\quad$ Flexural strength test according to ASTM C78 (Prism specimens of $100 \times 100 \times 400 \mathrm{~mm}$ ) [18].

- Water absorption test conducted according to ASTM C642 (Cube specimens of $100 \mathrm{~mm}$ ) [19].

- Dry density test according to ASTM C642(Cube specimens of $100 \mathrm{~mm}$ ) [19].

- Ultrasonic Pulse Velocity (UPV) According to the ASTM C597 (Cube specimens of $100 \mathrm{~mm}$ ) [20].

\section{Results and discussion}

\subsection{Selection of Mix Proportions for LWGPC}

Davidovits, [14] mention that geopolymer concrete attain most of its strength at early age, usually 7 days. Thus, in this investigation several trial mixes were adopted to select the LWGPC mix with proper density and compressive strength at 7 days age. The curing of fly ash lightweight geopolymer concrete is mostly carried out in previous researches at elevated temperatures; this is because the reaction of fly ash based geopolymer martial is so slow and usually show both slow setting and (slow?) strength development. All previous researchers conducted that curing time and curing temperatures significantly affect the compressive strength of geopolymer concrete $[8,9]$. The rise in curing temperatures and longer curing time increase the compressive strength. Table (4) shows the ingredients of all trial mixes prepared in this investigation, their fresh density, and compressive strength at 7 days. Different mix proportions of fly ash: sand: lightweight aggregate (Fa: S: LWA) were used. The fly ash content is varied between 342 and $540 \mathrm{~kg} / \mathrm{m}^{3}$; the superplasticizer was used as $1.9 \%$ from the weight of fly ash. The total water in the mix includes the water used in the activator solution and the water added to concrete. The water to fly ash ratio $(\mathrm{w} / \mathrm{Fa})$ used is between 0.25 and 0.61 , while the ratio of the activator solution to fly ash $(\mathrm{A} / \mathrm{Fa})$ is between 0.35 and 0.7 by mass. The molarity of $\mathrm{NaOH}$ solution used in the trial mixes is in the range of 10-16, while sodium silicate to sodium hydroxide solutions ratio remains at 2.5 for all trial mixes. The results demonstrate that geopolymer concrete mix (M8) has the highest compressive strength of 29.7 at 7 days, but its fresh density is high $\left(1980 \mathrm{~kg} / \mathrm{m}^{3}\right)$, so mix M10 is selected as lightweight geopolymer concrete with compressive strength of $27.3 \mathrm{MPa}$ at 7 days

and fresh density of $1951 \mathrm{~kg} / \mathrm{m}^{3}$ with fly ash content of $500 \mathrm{~kg} / \mathrm{m}^{3}$. The compressive strength for all trial mixes are shown in Fig. (2). In this research, the effect of alkali activator molarity and curing temperature on the compressive strength of the selected LWGPC mix was investigated. Three groups of LWGPC mixes were prepared using different activator molarities of 12,14 , 16 , each group is subjected to different curing temperatures of 60,80 and $90{ }^{\circ} \mathrm{C}$, as shown in Table (IV) and Fig.(3). The results show that as the alkali activator molarity increases, the density and compressive strength of LWGPC are increased too. Also the excess of curing temperature increases the compressive strength. It can be concluded that the selected mix has an alkali activator molarity of 16 and cured in temperature of $90{ }^{\circ} \mathrm{C}$ for 48 hours with compressive strength and fresh density of $32.8 \mathrm{MPa}$ and $1951 \mathrm{~kg} / \mathrm{m}^{3}$ at 7 days age[21]. The same conclusion for curing temperatures was found by other researcher[22]. Other researcher [23] reported that the increase in curing temperature improves the activation of fly ash, which raise the compressive strength and the increase in compressive strength is minor with the increase in duration of curing time from $24 \mathrm{hrs}$ to $48 \mathrm{hrs}$. Also, he specifies that the compressive strength of concrete will increase, whenever the molar concentration of sodium hydroxide liquid is increased.

\subsection{Properties of fresh lightweight Geopolymer concrete}

\subsubsection{Workability and fresh density}

Fly ash has hollow and spherical shape particles with smooth surface texture that lead to increase in the workability[24]. Fly ash lightweight geopolymer concrete prepared in this investigation has a good workability with slump value of $245 \mathrm{~mm}$ and fresh density of $1951 \mathrm{~kg} / \mathrm{m}^{3}$. 


\begin{tabular}{|c|c|c|c|c|c|c|c|}
\hline $\begin{array}{c}\text { Mix } \\
\text { Symbol }\end{array}$ & $\begin{array}{c}\text { Fa. } \\
\left(\mathrm{kg} / \mathrm{m}^{3}\right)\end{array}$ & $\begin{array}{c}\text { Mix proportion } \\
\text { Fa: S: LWA }\end{array}$ & A/Fa. & W/Fa. & $\begin{array}{c}\text { NaOH } \\
\text { molarity }\end{array}$ & $\begin{array}{c}\text { Fresh density } \\
\left(\mathrm{kg} / \mathrm{m}^{3}\right)\end{array}$ & $\begin{array}{c}\text { Compressive } \\
\text { strength at 7 days } \\
\left(\mathrm{N} / \mathrm{mm}^{2}\right)\end{array}$ \\
\hline M1 & 342 & $1: 2.40: 1.41$ & 0.59 & 0.61 & 12 & 1800 & 10.2 \\
\hline M2 & 350 & $1: 2.55: 1.62$ & 0.72 & 0.53 & 10 & 1810 & 8.3 \\
\hline M3 & 375 & $1: 2.26: 1.33$ & 0.4 & 0.34 & 14 & 1800 & 15.5 \\
\hline M4 & 460 & $1: 2.50: 0.60$ & 0.5 & 0.25 & 14 & 1850 & 18.2 \\
\hline M5 & 480 & $1: 0.73: 0.66$ & 0.35 & 0.34 & 14 & 1800 & 24.8 \\
\hline M6 & 460 & $1: 2.0: 0.60$ & 0.4 & 0.34 & 12 & 1830 & 14.5 \\
\hline M7 & 490 & $1: 1.32: 1.38$ & 0.60 & 0.35 & 10 & 1900 & 9.2 \\
\hline M8 & 490 & $1: 1.53: 1.22$ & 0.4 & 0.25 & 14 & 1980 & 29.7 \\
\hline M9 & 490 & $1: 1.73: 1.32$ & 0.4 & 0.25 & 12 & 2020 & 18.4 \\
\hline M10 & 500 & $1: 1.50: 1.10$ & 0.4 & 0.35 & 16 & 1951 & 27.3 \\
\hline M11 & 500 & $1: 1.60: 1.20$ & 0.6 & 0.35 & 16 & 2000 & 23.3 \\
\hline M12 & 500 & $1: 1.60: 1.10$ & 0.5 & 0.34 & 16 & 1950 & 21.2 \\
\hline M13 & 540 & $1: 0.78: 1.42$ & 0.4 & 0.31 & 14 & 1980 & 18.7 \\
\hline M14 & 540 & $1: 1.40: 0.92$ & 0.4 & 0.31 & 14 & 2020 & 20.2 \\
\hline M15 & 540 & $1: 1.10: 0.80$ & 0.4 & 0.31 & 14 & 1950 & 16.5 \\
\hline
\end{tabular}

Table 4. Trial mixes for lightweight GPC

Note1: The mix proportion is by weight; $\mathrm{Fa}=$ fly ash, $\mathrm{S}=$ sand, $\mathrm{LWA}=$ lightweight aggregate, $\mathrm{A}=$ activator, $\mathrm{W}=$ water.

Note 2: Curing temperature $=60^{\circ} \mathrm{C}$ for two days, superplasticizer dosage $=1.9 \%$ by weight of fly ash, sodium silicate: sodium hydroxide solutions $=2.5$ for all trial mixes.

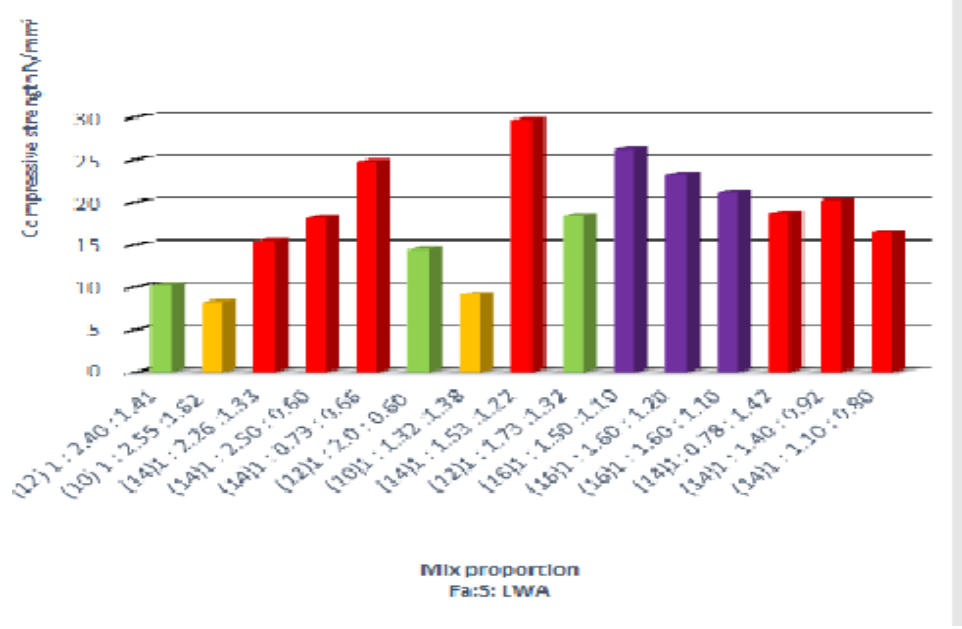

Fig 2. The compressive strength for all trial mixes

Table 5. Effect of activator molarity and rising curing temperatures on the compressive strength of LWGPC

\begin{tabular}{|c|c|c|c|c|c|c|c|}
\hline $\begin{array}{c}\text { Mix } \\
\text { symbol }\end{array}$ & $\begin{array}{c}\text { Fa. } \\
\left(\mathrm{kg} / \mathrm{m}^{3}\right)\end{array}$ & $\begin{array}{c}\text { Mix } \\
\text { proportion } \\
\text { Fa: S: LWA }\end{array}$ & $\begin{array}{c}\text { Alkali } \\
\text { activator } \\
\text { molarity }\end{array}$ & $\begin{array}{c}\text { Fresh density } \\
\left(\mathrm{kg} / \mathrm{m}^{3}\right)\end{array}$ & $\begin{array}{c}\text { Compressive strength at } \\
7 \text { days after curing } \\
\text { in } 60^{\circ} \mathrm{C} \text { for } 48 \text { hours } \\
\left(\mathrm{N} / \mathrm{mm}^{2}\right)\end{array}$ & $\begin{array}{c}\text { Compressive strength at } \\
7 \text { days after curing } \\
\text { in } 80^{\circ} \mathrm{C} \text { for } 48 \text { hours } \\
\left(\mathrm{N} / \mathrm{mm}^{2}\right)\end{array}$ & $\begin{array}{c}\text { Compressive strength at } 7 \\
\text { days after curing } \\
\text { in } 90^{\circ} \mathrm{C} \text { for } 48 \text { hours } \\
\left(\mathrm{N} / \mathrm{mm}^{2}\right)\end{array}$ \\
\hline GPLW1 & 500 & $1: 1.5: 1.1$ & 12 & 1943 & 18.2 & 20 \\
\hline GPLW2 & 500 & $1: 1.5: 1.1$ & 14 & 1945 & 25.6 & 27.3 \\
\hline GPLW3 & 500 & $1: 1.5: 1.1$ & 16 & 1951 & 27.3 & 30.2 \\
\hline
\end{tabular}




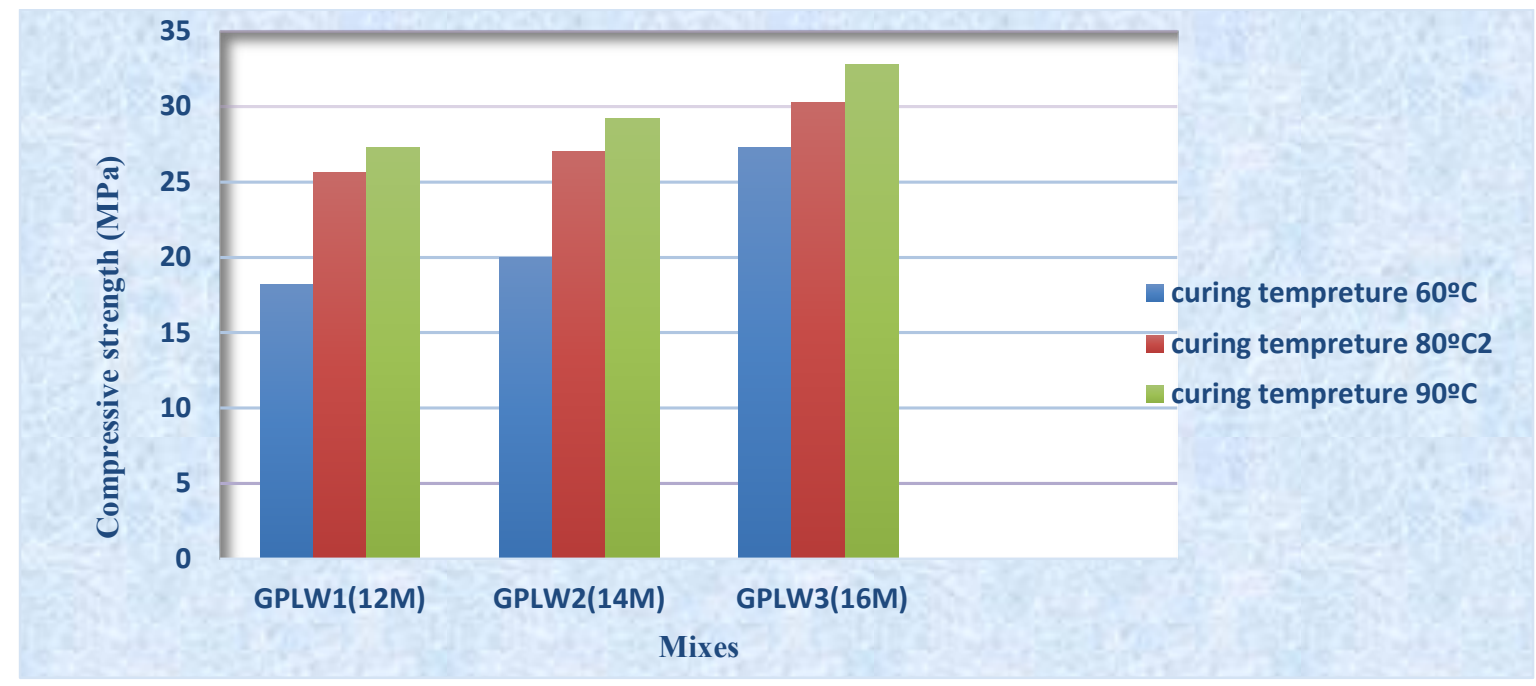

Fig. 3. The effect of rising the curing temperature on the compressive strength of LWGPC

Table 6. Properties of lightweight geopolymer concrete

\begin{tabular}{|c|c|c|c|c|c|c|c|c|}
\hline Mix proportion & Age (days) & $\begin{array}{l}\text { Compressive } \\
\text { strength }(\mathrm{MPa})\end{array}$ & $\begin{array}{l}\text { Splitting } \\
\text { tensile } \\
\text { strength } \\
(\mathrm{MPa})\end{array}$ & $\begin{array}{c}\text { Flexural } \\
\text { strength } \\
(\mathrm{MPa})\end{array}$ & $\begin{array}{l}\text { Oven dry } \\
\text { density } \\
\left(\mathrm{kg} / \mathrm{m}^{3}\right)\end{array}$ & $\begin{array}{c}\text { Water } \\
\text { absorption } \\
(\%)\end{array}$ & $\begin{array}{c}\text { Thermal } \\
\text { conductivity } \\
(\mathrm{W} / \mathrm{m} . \mathrm{K})\end{array}$ & $\begin{array}{c}\text { Pulse } \\
\text { velocity } \\
(\mathrm{m} / \mathrm{sec})\end{array}$ \\
\hline \multirow{4}{*}{$\begin{array}{c}\text { 1: } 1.5: 1.1 \\
\text { Fa: } \mathrm{S}: \text { LWA } \\
\text { (Fa ) contain } 500 \\
\mathrm{~kg} / \mathrm{m}^{3} \\
\text { curing } \\
\text { temperature } 90^{\circ}\end{array}$} & 7 & 32.8 & 2.22 & 4.6 & - & 8.27 & - & 4.15 \\
\hline & 14 & - & - & - & - & - & - & \\
\hline & 28 & 35.8 & 2.59 & 5.5 & 1835 & 7.5 & 0.9567 & 4.25 \\
\hline & 56 & 36.7 & 2.8 & 5.61 & - & 6.6 & - & 4.35 \\
\hline
\end{tabular}

\subsection{Properties of hardened lightweight Geopolymer concrete}

\subsubsection{Compressive Strength}

Table (5) and Fig (4) present the compressive strength of lightweight geopolymer concrete at 7, 28, and 56 days. Generally the compressive strength increases with age. The percentage increases are $9.5 \%$ and $12 \%$ at 28 and 56-day age, respectively relative to that at 7 days age. This is due to the continuous geopolymerization process.

\subsubsection{Splitting Tensile Strength}

Table (6) and Fig (5) present the splitting tensile strength of lightweight geopolymer concrete at 7, 28 and 56 days. Generally, the splitting tensile strength increases with age. The percentage increases are $16.7 \%$ and $26 \%$ at 28 and 56 days age, respectively relative to that at 7 days age. 


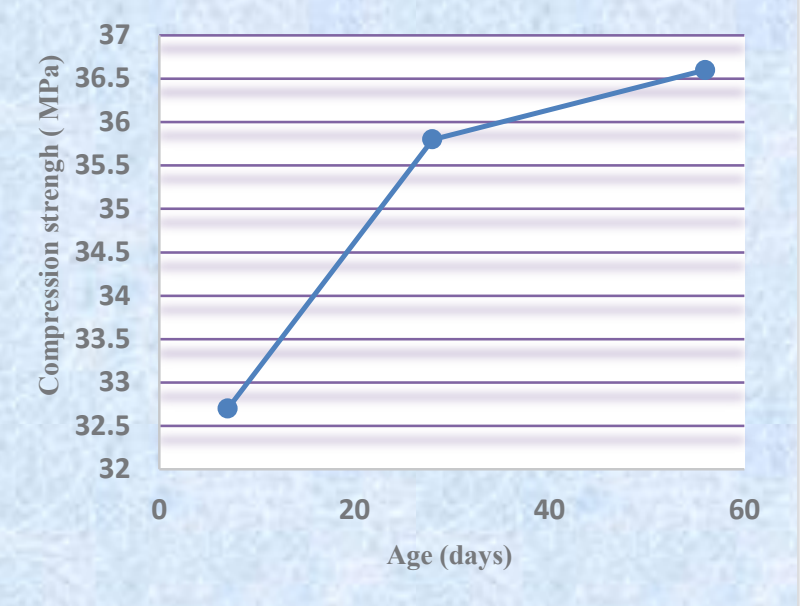

Fig. 4.Compressive strength development of LWGPC with age

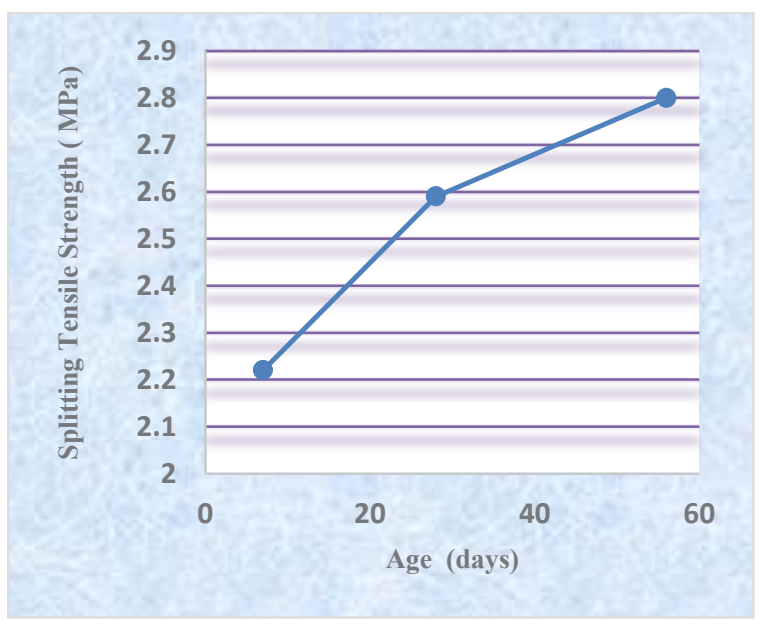

Fig. 5. Effect of age on the splitting tensile strength of LWGPC

\subsubsection{Flexural Strength}

Table (6) and Fig (6) present the flexural strength of lightweight geopolymer concrete at 7, 28, and 56 days. Generally, the flexural strength increases with age. The percentage increases are $19.5 \%$ and $22 \%$ at 28 and 56 days age, respectively relative to that at 7 days age.

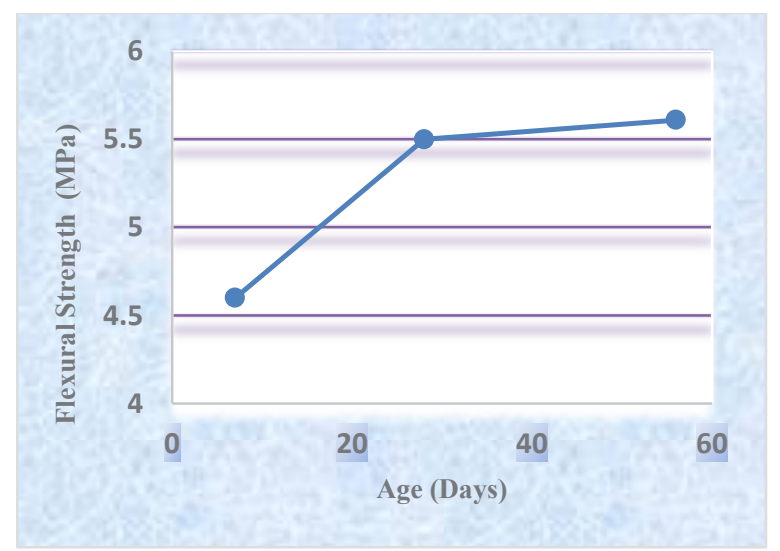

Fig. 6. Flexural strength development with age of LWGPC

\subsubsection{Water Absorption:}

The water absorption was conducted at different ages (7, 28 and 56) days. Water absorption decreases with the increase in age as shown in Table (6). This is because of hardening of the structure of fly ash geopolymer concrete with time. At all investigated ages, absorption values were less than 10 percent. According to Neville [5], most good concretes have an absorption value below 10 percent by mass. In addition to that, the absorption has a negative relationship with age and that is a good indication to the continuous geopolymerization process.

\subsubsection{Oven-dry density}

Oven-dry density for fly ash geopolymer concrete prepared in this investigation is $1835 \mathrm{~kg} / \mathrm{m}^{3}$ at 28 days age, thus, it satisfied the requirements of lightweight concrete.

\subsubsection{Ultrasonic Pulse Velocity (UPV)}

The UPV test is usually used to estimate the uniformity and quality of GPLWAC, specify the presence of voids, cracks, beside its evaluate the depth of the crack. The UPV values for geopolymer concrete specimens with artificial local lightweight aggregate are in the range of 4.15- $4.35 \mathrm{~km} / \mathrm{sec}$ as shown in Table (6). According to Neville[5] these values are considered as good quality concrete. The values of UPV obviously show the same trend for the compressive strength of LWGPC.

\subsubsection{Thermal conductivity}

The thermal conductivity of LWGPC is $0.9567 \mathrm{~W} /$ (m. K) at 28 days age. Normal weight concrete have thermal conductivity in the range of $1.98-2.94 \mathrm{~W} /(\mathrm{m}$. $\mathrm{K})$ depending on the type of aggregate used [25]. Lower thermal conductivity for lightweight geopolymer concrete is attributed to the presence of voids in lightweight aggregate. The low thermal conductivity of the produced LWGPC made it a good thermal insulating material.

\section{Conclusions}

The main findings of this research are as follows:

1. LWGPC can be produced using fly ash activated by alkali activator (sodium hydroxide:sodium silicate in a weight proportion of 1: 2.5) and locally artificial lightweight coarse aggregate.

2. The density and compressive strength of high strength LWGPC increase as the alkali activator molarity, curing temperature, and the age increase. 
3. The selected LWGPC mix, was containing fly ash of $500 \mathrm{~kg} / \mathrm{m}^{3}$ with alkali activator molarity of 16 and cured at temperature of $90^{\circ} \mathrm{C}$.

4. The compressive strength of LWGPC increases with age. Its value is $32.7,35.8$, and $36.8 \mathrm{MPa}$ at 7, 28, and 56 days, respectively. Whereas the percentage increases in splitting tensile strength is 16.7 and $26 \%$ at age 28 and 56 days, respectively relative to that at 7 days age. Also the flexure strength increases with age. The percentage increase is 19.5 and $22 \%$ at 28 and 56 days, respectively relative to that at 7 days age.

5. The produced high strength LWGPC has oven dry density and thermal conductivity of 1835 $\mathrm{kg} / \mathrm{m}^{3}$ and $0.9567 \mathrm{~W} /(\mathrm{m} . \mathrm{K})$ at 28 days age, respectively.

6. The produced high strength LWGPC is classified as insulated structural lightweight concrete, in addition it is an environmentally eco-friendly concrete.

\section{References}

[1] A. S.Pratik, B. shinde, and Amit, D. chougule., International Research Journal of Engineering and Technology (IRJET), 3, (2016).

[2] A. D. Najmabadi, Faculty of Civil Engineering Universiti Teknologi Malaysia JANUARY, Master of Engineering (Civil - Structure), (2012).

[3] E. Ivan Diaz-Loya, E. N. Allouche, and S. Vaidya, ACI materials journal, 108, (2011).

[4] E. Gartner, Cement and Concrete research, vol. 34, pp. 1489-1498, 2004.

[5] A. M. Neville, Properties of concrete, Fourth and final edition, Longman Group, Ltd., (2005).

[6] O. Kayali, Construction and Building Materials, 22, pp. 2393-2399, (2008).

[7] S.-C. $\mathrm{Ng}$ and K.-S. Low, Energy and Buildings, 42, pp. 2452-2456, (2010).

[8] S. P. G. Babu2, Transactions on Engineering and Sciences . 2, October (2014).

[9] ASTM C618, Standard Specification for Coal Fly Ash and Raw or Calcined Natural Pozzolan for Use in Concrete, American Society for Testing and Materials. (2002)

[10] ASTM C494 / C494M, Standard Specification for Chemical Admixtures for Concrete, American Society for Testing and Materials.(2005)

[11] ASTM C330-03, Standard Specification for Lightweight Aggregates for Structural Concrete, American Society for Testing and Materials. ( 2003).
[12] N. A. Lloyd, and V. Ranjan, Proceedings of the 10th ACI International Conference on Recent Advances in Concrete Technology and Sustainability Issues, Seville, ACI SP- 261, pp. 33-54., (2009).

[13] S. H. a. K., and Sanni, R.B., International Journal of Research in Engineering and Technology, pp. 366-371, (2013).

[14] ASTM C143-03, Standard Test Method for Slump of Hydraulic-Cement Concrete, ASTM International, American Society for Testing and Materials, 04-02, United States, (2004).

[15] ASTM C127, Standard Test Method for Density Relative Density (Specific Gravity) and Adsorption of Coarse Aggregate, American Society for Testing and Materials, 04-02, United States, (2004).

[16] BS 1881, Part 116, Method for Determination of Compressive Strength of Concrete Cubes, British Standards Institution, 1881.( 1989).

[17] ASTM C496, Standard Test Method for Splitting Tensile Strength for Cylindrical Concrete Specimens, American Society for Testing and Materials. 04-02, (2004) .

[18] ASTM C78-02, Standard Test Methods for Flexural Strength of concrete (Using Sample Beam with Third Point Loading), American Society for Testing and Materials. Vol. 04.02, (2004).

[19] ASTM C642-97, Standard Test Method of Specific Gravity, Absorption and Voids in Hardened Concrete, American Society for Testing and Materials. Vol. 04-02, 1997.

[20] ASTM C597, Standard Test Method for Pulse Velocity through Concrete, American Society for Testing and Materials, Vol. 04-02,( 2015).

[21] Mohammed R. Nagral, Tejas Ostwal, and Manojkumar V. Chitawadagi, International Journal of Computational Engineering Research (IJCER),4,( 2014).

[22] A. Palomo, M.W. Grutzek, and M.T. Blanco, Cement and Concrete Research,, vol. 29, pp. pp. 1323-1329,(1999).

[23] S. V. Joshi, and M. S. Kadu, International Journal of Environmental Science and Development, 3, (2012).

[24] J. Davidovits, "Geopolymer Chemistry and Applications",3rd edition, Institut Géopolymère, France., (2011) .

[25] B. Milovanovic, I.B. Pecur, and I.Gabrijiel, Novel Development and Innovation in Cementitious Materials, Imperial College, London, United Kingdom, 12, pp.1-5, (2011). 